
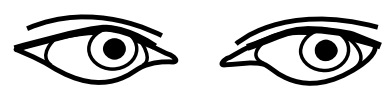

\title{
Jämlikhet och individanpassning - ett realistiskt ideal för den svenska äldreomsorgen?
}

\author{
MARTA SZEBEHELY
}

Att äldre människor ska få lika god äldreomsorg oavsett plånbokens storlek är en självklar utgångspunkt i svensk välfärdspolitik. Det kommer till uttryck i de äldrepolitiska riktlinjer som antogs 1998 och som fortfarande är de som gäller i Sverige: äldreomsorgen ska vara "solidariskt finansierad genom skattemedel" och "tillgänglig efter behov, inte efter köpkraft"'(Regeringens prop. 1997/98:113 s. 1). En liknande ambition kommer till uttryck i socialtjänstlagens portalparagraf: "Samhällets socialtjänst skall på demokratins och solidaritetens grund främja människornas (...) jämlikhet i levnadsvillkor" (SoL 1 kap., 1 §). Den här betoningen av solidarisk finansiering och jämlik fördelning brukar ses som en central aspekt av den universella välfärdsmodell som internationella forskare ser som (mer eller mindre) karakteristisk för de nordiska välfärdsstaterna.

Samtidigt betonar såväl socialtjänstlagen som de äldrepolitiska riktlinjerna att äldreomsorgen ska respektera den äldres självbestämmande och individuella önskemål (se t.ex. Regeringens prop. 1997/98:113 s. 61, 91). Den svenska äldreomsorgen ska således både sträva efter att främja jämlika villkor och samtidigt individuellt anpassa omsorgsinsatserna enligt enskilda äldres önskemål. Finns det då en motsättning mellan dessa ambitioner? Kan den generella välfärdsmodellen vara individanpassad? Min tes i den här texten är att en individuellt 
anpassad omsorg inte bara är förenlig med universalism, utan att individanpassning är en förutsättning för en universell äldreomsorg. Jag hävdar också att trots att jämlikhet fortfarande finns kvar i policydokument och lagstiftning, och trots att den enskildes självbestämmande har kommit att betonas alltmer i de nationella politiska dokumenten så har organisatoriska och resursmässiga förändringar gjort det svårare för äldreomsorgens personal att i praktiken leva upp till ambitionen att såväl främja jämlika villkor som att individuellt anpassa omsorgsinsatserna till olika äldres skiftande situation och önskemål.

I ett nyligen publicerat bokkapitel diskuterar Gun-Britt Trydegård och jag detta (Szebehely \& Trydegård 2014). Vi tar vår utgångspunkt $i$ en central aspekt av universalism, nämligen målsättningen att samma slags tjänster ska utnyttjas av alla sociala grupper för att på så sätt främja jämlika levnadsvillkor. Rötterna finns i folkhemstanken att om alla sociala grupper använder sig av samma slags tjänster så gynnas även de som är mindre priviligierade. Om till exempel medelklassens äldre bor på samma sjukhem som fattiga äldre så får de mindre resursstarka äldre en bättre äldreomsorg än om det finns skilda sjukhem för rik och fattig. Detta eftersom det är svårt att upprätthålla kvaliteten i sociala verksamheter som riktas enbart till fattiga grupper. Som Richard Titmuss har uttryckt det (1968 s. 134): "services for poor people have always tended to be poor quality services". Centralt här är att de mer resursstarka äldre - eller snarare deras anhöriga - har en viktig roll som övervakare och pådrivare av omsorgskvalitet.

Men för att alla sociala grupper ska vara villiga att använda samma slags omsorgstjänster måste tjänsterna vara attraktiva även för den som har det bättre ställt. Om inte tjänsterna är av tillräckligt god kvalitet kommer de som har ekonomiska möjligheter att välja bort det offentliga erbjudandet och söka sig till helt privata lösningar eller toppa upp de skattefinansierade insatserna med privat köpt hjälp. Den tankegången kan sammanfattas i ett uttryck som brukar tillskrivas folkhemmets arkitekt Gustav Möller: "Endast det bästa är gott nog åt folket”.

För att äldreomsorgen ska kunna vara "god nog" även för mer resursstarka grupper i samhället så måste äldreomsorgen vara tillräckligt generöst finansierad och välutbyggd. Där har vi ett problem idag. Sedan flera decennier har de offentliga resurserna inte hållit jämna steg med den åldrande befolkningen. Äldreomsorgen har stramats åt: tröskeln för att beviljas en plats i äldreboende har höjts påtagligt sedan millennieskiftet och i förhållande till de äldres behov tilldelas hemtjänstinsatser betydligt mindre generöst än för ett par decennier sedan. Samtidigt har anhörigas omsorgsinsatser ökat, framför allt bland mindre resursstarka grupper av äldre, medan äldre med högre pensioner $\mathrm{i}$ stället till viss del har kompletterat hemtjänstens åtstramning med privat köpt hjälp (Szebehely \& Trydegård 2014).

En generös offentlig finansiering är en nödvändig men inte tillräcklig förutsättning för en attraktiv äldreom- 
sorg. För att äldreomsorgen ska vara "god nog" så måste insatsen också ta hänsyn till den enskilde äldres personlighet, vanor och önskemål."One-size-fits-all"kan aldrig känneteckna en attraktiv äldreomsorg. En attraktiv äldreomsorg måste vara individoch situationsanpassad. Även här finns det problem idag.

När den svenska hemtjänsten började byggas ut under 1950- och 60-talen blev den snabbt populär i alla sociala skikt. Det berodde på att den var både universell och individanpassad. Den riktade sig till alla som behövde hjälp i sin vardag, inte bara de fattigaste eller sjukaste. Men den behandlade inte alla lika.

Den tidiga hemtjänstens organisationsmodell karakteriserades av fasta relationer mellan personal och hjälptagare, hjälp på i förväg bestämda tider och en låg grad av förhandsstyrning och kontroll och därmed ett relativt stort handlingsutrymme för personalen - och därigenom också för hjälptagarna. Hemsamariterna, som yrkesgruppen kallades då, hade personlig kunskap om hjälptagaren och handlingsfrihet nog att anpassa hjälpen till det begränsade antal äldre personer som de hade att förhålla sig till. Arbetet var inte styrt av rutiner och detaljerade scheman och hjälptiden var relativt generöst tilltagen; det fanns utrymme för personalen att tänka själv och känna efter vad som är rätt för just den här personen vid just det här tillfället. De hade med andra ord möjlighet att handla enligt den logik som Kari Wærness (1984) betecknar omsorgsrationalitet.

Det finns vid det här laget en mängd svenska och internationella forsknings- resultat som visar att god omsorgskvalitet förutsätter att insatsen flexibelt anpassas efter olika individers vardagsvanor och varierande situation. Det kräver i sin tur att det finns tid i omsorgsmötet, kontinuitet mellan omsorgsgivare och mottagare samt att personalen har tillräckligt stort handlingsutrymme.

De organisationsförändringar som har genomförts i den svenska hemtjänsten har dock gått stick i stäv med forskningens insikter. Resursåtstramning och neddragning av antalet äldreboendeplatser har gjort hemtjänstens arbete mer tidspressat, och besöken till de allt mer hjälpbehövande äldre har blivit fler och kortare. Marknadsinfluerade organisationsmodeller och styrformer - New Public Management (NPM) - har fått allt större genomslag. Biståndsbesluten som styr personalens arbete har blivit mer detaljerade. I takt med att allt fler kommuner har introducerat kundvalsmodeller ökar kraven på tydliga beställningar och kontroll. Olika instrument har utvecklats för att kontrollera att det utförda arbetet är i överensstämmelse med beställningen, och allt mer energi läggs på dokumentation och kvalitetsmätning med fokus på de aspekter av hjälpen som är "mätbara" men långtifrån alltid de som är de viktigaste för den äldre. Dessa förändringar begränsar personalens handlingsutrymme och därmed har möjligheten att ge en situations- och individanpassad omsorg på flera sätt försämrats.

Om hemtjänstens möjligheter att ge omsorg som är "god nog" har försämrats så finns det en del som talar för en mer positiv utveckling när det gäller äldrebo- 
endena. I det lite längre tidsperspektivet skulle jag vilja påstå att förutsättningarna för en individuellt anpassad omsorg i äldreboenden på flera sätt har förbättrats. Jämfört med långvårdens stelbenta vårdrutiner har personalen fått större handlingsutrymme och bättre möjligheter att behandla de boende som de olika individer de faktiskt är. Men samtidigt har omsorgsbehoven ökat och personaltätheten har knappast ökat i motsvarande grad, och visst händer det att den äldres inflytande i vardagen begränsas både av personalens tidsbrist och av regler och rutiner (Whitaker 2004; Harnett 2010).

Personalens arbetsvillkor hänger nära samman med äldreomsorgens kvalitet. För att välfärdsstaten ska kunna leva upp till åtagandet att ge medborgarna "god nog" äldreomsorg måste omsorgspersonalen ha rimliga arbetsvillkor. Men många som arbetar i såväl äldreboenden som hemtjänst upplever att deras arbetsvillkor och möjligheten att möta de äldres behov har försämrats, vilket leder till känslor av otillräcklighet och en flykt från arbetet. Arbetet är fysiskt och psykiskt tungt, och äldreomsorgens kvinnodominerade personal drabbas av arbetsskador, sjukskrivning och förtidspension i oproportionerlig utsträckning. Även personalens villkor borde omfattas av äldreomsorgens jämlikhetsambitioner - det borde vara en jämlikhetsfråga att personalen inom omsorgssektorn inte ska behöva bära kostnaden för otillräckliga resurser och illa fungerande organisationsformer på sina egna kroppar (Stranz 2013).

Så var står vi idag när det gäller den universella omsorgsmodellens löften om jämlik och individanpassad äldreomsorg? Ser framtiden ljus eller mörk ut? Det är förstås inte så lätt att veta men jag vill gärna vara optimistisk. Av flera skäl. När medborgarna tillfrågas om de vill betala mer skatt för olika välfärdsområden kommer äldreomsorgen oftast högst upp på listan. Man brukar säga att de nordiska länderna präglas av en "passion for equality" och jag är ganska övertygad om att de allra flesta svenskar vill att alla ska ha rätt till lika välfungerande och individuellt anpassade omsorgstjänster - oavsett plånbokens storlek. Jag tror också att de flesta inser att det förutsätter att också personalen måste ha goda arbetsvillkor så att även de kan åldras med tillförsikt.

När detta skrivs har vi just fått en ny regering som i dagarna har presenterat sin första budget. Jag noterar att det finns en del ljusglimtar där. Statliga bidrag till kommunerna om två miljarder för att öka personaltätheten inom äldreomsorgen är kanske det mest konkreta löftet i det här sammanhanget; en satsning som förväntas leda till både höjd kvalitet och förbättrad arbetsmiljö. Jag noterar också att nya mål för äldrepolitiken ska formuleras under 2015 och att utgångspunkter för arbetet är "jämlikhet, trygghet, delaktighet och inflytande". Jämlikhet har en tydligare plats i dokumentet än vad som varit fallit under senare år (under såväl borgerliga som tidigare socialdemokratiska regeringar) samtidigt som vikten av individuell anpassning fortfarande betonas: "Kvinnor och män har rätt att livet igenom bli bemötta som individer med olika behov och önskemål." Det finns också formuleringar som ligger tydligt i linje med Gustav 
Möllers argumentation om att välfärdstjänster ska vara av så god kvalitet att de offentligt finansierade verksamheterna är attraktiva även för mer resursstarka grupper: "Kvaliteten ska vara så hög att de äldre inte behöver komplettera omsorgen genom att köpa tilläggstjänster för att uppnå skälig standard och att anhöriga till äldre inte ska behöva gå ner i arbetstid för att kompensera för brister i omsorgen." (Regeringens prop. 2014/15:1, s. 167).

Strax före valet utlovade också socialdemokraterna att tillsätta en utredning om "välfärdens styrning efter $\mathrm{New}$ Public Management". Problemformuleringen ligger nära den som jag har skisserat här:

"Många yrkesgrupper som tidigare var självständiga professionella vittnar om att de har nedvärderats till detaljstyrda utförare. Arbetet har styckats upp i enkelt mätbara delar som kopplas till resursfördelning. Det betyder ofta en pressad arbetssituation och svårigheter att följa lagar och yrkesetik. Mer svårmätta delar av arbetet, som omsorg och social samvaro, kommer sällan med i dessa enkelt mätbara delar. Den omsorgskompetens som både bidrog till kvalitet och fick arbetet att flyta har försvunnit i den ekonomiska detaljstyrningen." (Socialdemokraterna 2014, s. 3).

I dokumentet betonas att förändringsarbetet ska genomföras i "nära samarbete med företrädare för välfärdens professioner, forskningen och brukarna", att professionernas kunnande och yrkesetik ska vara vägledande och att de nya styrmodellerna ska leda till större frihet för medarbetarna i offentlig sektor och därmed bidra till att utveckla välfärden (ibid., s. 9).

Det är uppenbart att de skisserade förändringarna är betydligt bättre grundade i den omfattande omsorgsforskningens insikter än de marknadsinfluerade organisationsförändringar som präglat äldreomsorgen och andra välfärdstjänster under de senaste decennierna. Om de lovvärda initiativen kommer att leda till faktiska förbättringar återstår naturligtvis att se, inte minst eftersom det politiska läget är så osäkert - när jag fick korrekturet på artikeln hade regeringens budget redan fallit. Men jag väljer som sagt att vara optimistisk. Inte minst eftersom äldreomsorgen berör så många människor att det är en fråga som inga politiker kan blunda för. 


\section{Referenser}

Harnett, T. (2010) The trivial matters: everyday power in Swedish elder care (doktorsavhandling). Jönköping University, School of Health Sciences.

Regeringens prop. 1997/98:113. Nationell handlingsplan för äldrepolitiken.

Regeringens prop. 2014/15:1. Budgetpropositionen för 2015, Utgiftsområde 9, Hälsovård, sjukvård och social omsorg.

Socialdemokraterna (2014) Ny styrning i välfärden efter New Public Management - Lät proffsen vara proffs. PM 2014-09-05. http://www. socialdemokraterna.se/Pressrum/nyheter/ Ny-styrning-i-valfarden-/ (nedladdat 201410-24).

Stranz, A. (2013) Omsorgsarbetets vardag och villkor i Sverige och Danmark: Ett feministiskt kritiskt perspektiv (doktorsavhandling). Stockholms universitet, Institutionen för social arbete.

Szebehely, M. \& Trydegård , G.-B. (2014) Hur mycket självbestämmande ryms det i skälig levnadsnivå? Socialtjänstlagens visioner och äldreomsorgens realiteter. I: Pettersson, U., red: Tre decennier med socialtjänstlagen utopi, vision, verklighet. Malmö: Gleerups.

Titmuss, R.M. (1968) Commitment to Welfare. London:Allen and Unwin.

Wærness, K. (1984) The rationality of caring. Economic and Industrial Democracy, 5 (2) 185-211. Whitaker, A. (2004) Livets sista boning - Anhörigskap, åldrande och död på sjukhem (doktorsavhandling). Stockholms universitet, Institutionen för socialt arbete. 